\title{
Illuminating the structure of convective cold pools with a dense station network
}

\author{
Bastian Kirsch ${ }^{1,4}$, Cathy Hohenegger ${ }^{2,4}$, Daniel Klocke ${ }^{3,4,2}$, Rainer Senke ${ }^{1}$, Michael Offermann ${ }^{1}$, and \\ Felix Ament ${ }^{1,2,4}$ \\ ${ }^{1}$ Meteorological Institute, University of Hamburg, Germany \\ ${ }^{2}$ Max Planck Institute for Meteorology, Hamburg, Germany \\ ${ }^{3}$ Deutscher Wetterdienst, Offenbach am Main, Germany \\ ${ }^{4}$ Hans Ertel Centre for Weather Research, Branch Model Development - Convection, Hamburg, Germany
}

Correspondence: Bastian Kirsch (bastian.kirsch@uni-hamburg.de)

\begin{abstract}
From June to August 2020 an observational network of 103 meteorological ground-based stations covered the greater area $(50 \mathrm{~km} \times 35 \mathrm{~km})$ of Hamburg (Germany) as part of the Field Experiment on Sub-mesoscale Spatio-Temporal variability in Hamburg (FESST@HH). The purpose of the experiment was to shed light on the sub-mesocale $(\mathcal{O}(100) \mathrm{m}-\mathcal{O}(10) \mathrm{km})$ structure of convective cold pools that typically remains under-resolved in operational networks. During the experiment, 82 custom-built, low-cost APOLLO (Autonomous cold POoL LOgger) stations sampled air temperature and pressure with fastresponse sensors at $1 \mathrm{~s}$ resolution to adequately capture the strong and rapid perturbations associated with propagating cold pool fronts. A secondary network of 21 weather stations with commercial sensors provided additional information on relative humidity, wind speed and precipitation at $10 \mathrm{~s}$ resolution. The realization of the experiment during the COVID-19 pandemic was facilitated by a large number of volunteers who provided measurement sites on their premises and supported the station maintenance. This article introduces the novel type of autonomously operating instruments, their measurement characteristics and the FESST@HH data set (https://doi.org/10.25592/UHHFDM.8973; Kirsch et al., 2021b). A case study demonstrates that the network is capable of mapping the horizontal structure of the temperature signal inside a cold pool as well as quantifying its size and propagation velocity throughout its life cycle. Beyond its primary purpose, the data set offers new insights into the spatial and temporal characteristics of the nocturnal urban heat island and variations of turbulent temperature fluctuations as an expression of different urban and natural environments.
\end{abstract}

\section{Introduction}

We present the instrumentation and data set of the Field Experiment on Sub-mesoscale Spatio-Temporal variability in Hamburg (FESST@HH) that illuminates the spatial and temporal structure of convective cold pools. Conventional meteorological station networks have a typical resolution of $\sim 25 \mathrm{~km}$ in space and $10 \mathrm{~min}$ in time and are essential to obtain a reliable picture of the atmospheric background state. Remote sensing techniques help us to retrieve more-finely resolved information for a few atmospheric variables like precipitation or wind speed. However, the spatial variability of basic meteorological parameters like air temperature or pressure on the sub-mesoscale (i.e., length scales between $\mathcal{O}(100) \mathrm{m}$ and $\mathcal{O}(10) \mathrm{km}$ ) remains under-resolved. 
https://doi.org/10.5194/essd-2021-424

Preprint. Discussion started: 3 March 2022

(c) Author(s) 2022. CC BY 4.0 License.

(c) (i)

The information on sub-mesoscale variability is especially important for the investigation and simulation of convective clouds and precipitation (Stevens et al., 2020). Convective cold pools are an important source of this variability and, therefore, represent a blind spot for conventional observation networks. This fact qualifies them as the main motivation for the FESST@HH experiment.

Cold pools play a prominent role for understanding the formation and life cycle of atmospheric convection. They are defined as areas of relatively cool and dense air that form through melting and evaporation of hydrometeors underneath precipitating clouds. Their horizontal size range from a few $\mathrm{km}$ to several tens of $\mathrm{km}$ (Terai and Wood, 2013; Feng et al., 2015) with temperature falling by more than $10 \mathrm{~K}$ (Engerer et al., 2008; Kirsch et al., 2021a). As the body of cold air grows and propagates away from the precipitation, it often causes a rapid decrease in local air temperature and the formation of a gust front. Secondary updrafts are preferentially triggered in the region ahead of the cold pool air due to the combination of mechanical lifting and accumulation of moisture in the lower troposphere (Tompkins, 2001; Feng et al., 2015; Torri et al., 2015). Cold pools are also found to support the organization of convective clouds and the transition from shallow to deep convection (Khairoutdinov and Randall, 2006; Schlemmer and Hohenegger, 2014; Kurowski et al., 2018). Since models with hectometer-scale resolution are required to realistically represent processes related to convection (Bryan et al., 2003; Grant and Heever, 2016; Hirt et al., 2020), large-eddy simulations (LES) have become an established tool to study cold pools. However, LES models critically depend on parametrizations of subgrid-scale phenomena, such as turbulence and microphysics (Daw; Li et al., 2015). This fact supports the need for observational data with a similar resolution to LES models that facilitate validation of simulations and enhance our understanding of sub-mesoscale processes.

Observational studies on cold pools draw upon a wide range of data-collection methods. These include measurements from boundary layer towers (Goff, 1976; Kirsch et al., 2021a), aircrafts (Terai and Wood, 2013), ships (Szoeke et al., 2017), precipitation radars (Borque et al., 2020), and combinations thereof (Mueller and Carbone, 1987; Feng et al., 2015). Nevertheless, capturing the horizontal structure of cold pools with the help of in situ observations is a challenging task given the small number of studies using, e. g., mesoscale station networks (Markowski et al., 2002; Engerer et al., 2008). In a recent study, van den Heever et al. (2021) described the use of uncrewed aerial systems, radiosondes and surface stations during the C ${ }^{3}$ LOUDEx campaign to characterize the structure of convective updrafts and downdrafts on scales between $\mathcal{O}(100) \mathrm{m}$ and $\mathcal{O}(1) \mathrm{km}$, whereas their surface network consisted of only three points. There are also examples of more extensive observation networks at km-scale resolution, like the the Oklahoma City Micronet (Basara et al., 2011) and the WegenerNet (Kirchengast et al., 2014). However, with respect to areal coverage and instrument characteristics, these networks were mainly designed for climate monitoring rather than investigating short-lived convective-scale processes like cold pools.

The FESST@HH field experiment took place in Hamburg (Germany) from June to August 2020. The idea of the experiment was to perform meteorological observations that are suited to capturing the spatial structure of cold pools at the sub-mesoscale. This goal required the design of a ground-based station network that is large enough to cover the typical size of a cold pool $(\mathcal{O}(10) \mathrm{km})$ and dense enough to satisfy the desired resolution $(\mathcal{O}(100) \mathrm{m})$. Additionally, the measurement instruments had to be equipped with appropriate sensors for capturing cold pool fronts but still cheap enough to be deployed in large numbers. The relatively long measurement period was chosen to catch a reasonable number of cold pools during the convective season 
https://doi.org/10.5194/essd-2021-424

Preprint. Discussion started: 3 March 2022

(c) Author(s) 2022. CC BY 4.0 License.

(c) (i)

in Hamburg, where around seven events per month are expected (Kirsch et al., 2021a). In this article, we introduce the novel instruments and data set of FESST@HH and demonstrate its potential for investigating the spatial structure and life cycle of cold pools based on a case study. Moreover, the experimental setup allows to study the spatial dimension of the nocturnal urban heat island as well as the variability of turbulent temperature fluctuations in different environments. A special feature of FESST@HH was the participation of a large number of volunteers that became necessary in response to the COVID-19 pandemic.

\section{Design of instruments}

The instrument design for the FESST@HH experiment was guided by the technical demands required to observe the submesoscale structure of cold pools in space and time. Most importantly, the instruments had to be equipped with fast-response air temperature sensors that precisely capture relative changes in temperature. The sampling interval required was $\Delta t \leq 10 \mathrm{~s}$ in order to track the propagation of cold pool fronts with a velocity of about $10 \mathrm{~m} \mathrm{~s}^{-1}$ (Borque et al., 2020) on scales of $\mathcal{O}(100) \mathrm{m}$. Moreover, the instruments had to operate independent of an external power source for about two weeks to facilitate the search for appropriate site locations. According to these requirements, we designed and manufactured the Autonomous cold POoL LOgger (APOLLO) for operation during the FESST@HH experiment. We complemented the network with WXT weather stations based on commercial sensors.

\subsection{APOLLO}

The APOLLO is a simple and low-cost data logger that records air temperature and pressure. Inspired by the pyranometer network stations used during the HOPE campaign (Madhavan et al., 2016), it operates autonomously without an external power source and its sensor and control units are mounted on a short mast (Fig. 1). The APOLLO is equipped with a fastresponse and moisture-resistant thermometer consisting of a small $(7 \mathrm{~mm} \times 1.2 \mathrm{~mm})$ NTC (negative temperature coefficient) thermistor probe (type: TE Connectivity GA10K3MRBD1; Fig. 2a) placed inside a radiation shield (see sensor specifications in Table 1). The design and size of the sensor allow for very small response times according to a time constant $\tau=14 \mathrm{~s} \pm 10 \%$ at $3 \mathrm{~m} \mathrm{~s}^{-1}$ wind speed that we determined in wind tunnel laboratory tests. The control unit is based on a micro controller board (type: HIMALAYA Matrix-Core ESP32) located inside a small $(26 \mathrm{~cm} \times 17 \mathrm{~cm} \times 10 \mathrm{~cm})$ logger box (Fig. 2b). A digital air pressure sensor (type: Bosch BME280 Environmental sensor) is installed on the logger main board, whereas a counterbalance valve ensures rapid adjustment of barometric pressure inside the logger box.

The readings of the temperature and pressure sensors are sampled with a resolution of $1 \mathrm{~s}$ and written onto a micro-SD memory card. An on-board GPS receiver is used to initially synchronize the internal real-time clock on start of the logger. To minimize power consumption during operation, the GPS module is activated to log the current time only once per hour for about $10 \mathrm{~s}$, which allows to correct the logger time stamp for drifting in a post-processing step. The logger can establish a local WiFi hotspot for on-site control and data inspection and is able to send status telegrams via the LoRa (Long Range) wireless communication protocol for live monitoring. 
https://doi.org/10.5194/essd-2021-424

Preprint. Discussion started: 3 March 2022

(c) Author(s) 2022. CC BY 4.0 License.

(c) (i)

The APOLLO is powered by a standard USB power bank battery (20 Ah capacity) that corresponds to an autonomous operation time of 10 to 14 days. For easy access during maintenance, the power bank is placed inside a separate plastic tube. All logger units are mounted on a $3 \mathrm{~m}$ mast that is anchored in the soil with a ground screw. In the standard configuration, the temperature sensor at the top of the mast and the pressure sensor inside the logger box are situated about $2.9 \mathrm{~m}$ and $1.7 \mathrm{~m}$ above ground, respectively. The material costs for all required parts sum up to around 300 Euro per logger.

The APOLLO station proves suitable for accurately recording cold pool front passages in field measurements. The comparison with an inertia-free ultrasonic sensor confirms that the NTC thermometer responds almost instantaneously to the rapid cooling signature of a cold pool event and even captures high-frequency temperature fluctuations (Fig. 3). Test measurements also show that external site conditions, such as surrounding obstacles or different surface properties, do not have a considerable impact on the cold pool signal (not shown) and, therefore, do not restrict the choice of the measurement site.

\subsection{WXT weather station}

WXT weather stations are employed to complement the APOLLO stations by providing information on other common meteorological parameters at selected locations. The main component of the station is a commercial compact multi-parameter sensor (type: Vaisala Weather Transmitter WXT536) that measures air pressure, temperature, relative humidity, wind speed, wind direction and precipitation (see sensor specifications in Table 2). Pressure, temperature and relative humidity measurements are performed by a PTU module inside a radiation shield that combines a capacitive silicon BAROCAP sensor (pressure), a resistive thin-film Pt1000 sensor (temperature) and a capacitive thin-film polymer HUMICAP R2 sensor (relative humidity). Wind speed and wind direction are detected by an WINDCAP ultrasonic anemometer on top of the radiation shield that consists of three equally-spaced ultrasonic transducers on a horizontal plane. The wind measurements are determined from the transit times of the ultrasound along the three paths with a sampling rate of $4 \mathrm{~Hz}$ and are internally averaged. The precipitation measurement principle of the WXT536 sensor is based on a RAINCAP piezoelectrical sensor underneath a steel cover that detects the impacts of individual rain drops within a collecting area of $60 \mathrm{~cm}^{2}$. Since the individual signals are proportional to the size of the rains drops, the sensor is able to derive the accumulated rainfall amount within the measurement interval. The sensor also distinguishes between impacts of rain drops and hail stones (Vaisala, 2020). Additionally, the WXT station is equipped with an external Pt1000 thermometer (type: TMH cable sensor Pt1000 1/3 DIN Klasse B; size: $40 \mathrm{~mm} \times 3 \mathrm{~mm}$ ) inside a separate radiation shield that allows for smaller response times of the measured temperature signal $(\tau=55 \mathrm{~s} \pm 10 \%$ at $3 \mathrm{~m} \mathrm{~s}^{-1}$ wind speed) than the internal PTU module ( $\tau=213 \mathrm{~s} \pm 10 \%$ at $3 \mathrm{~m} \mathrm{~s}^{-1}$ wind speed).

The WXT data are sampled at $10 \mathrm{~s}$ resolution and written onto a SD memory card by a data logger (type: Avisaro M22766) that is synchronized with an integrated GPS module. The units of the station are powered by a $12 \mathrm{~V}$ lead battery. The battery is recharged by a solar panel $(67 \mathrm{~cm} \times 41 \mathrm{~cm})$ so that the station can operate autonomously for several months, depending on the available sun light. Similar to the APOLLO design, the station components are mounted on a $3 \mathrm{~m}$ mast that is anchored in the soil with a ground screw (Fig. 4). 
https://doi.org/10.5194/essd-2021-424

Preprint. Discussion started: 3 March 2022

(c) Author(s) 2022. CC BY 4.0 License.

\section{Description of experiment}

The FESST@HH measurement campaign took place under extraordinary circumstances. Its name is a modification of the acronym FESSTVaL (Field Experiment on Sub-mesoscale Spatio-Temporal Variability in Lindenberg), a field campaign that was originally planned to take place at the Meteorological Observatory Lindenberg (eastern Germany) during summer 2020. Due to travel restrictions in response to the COVID-19 pandemic, the decision was made to postpone the FESSTVaL campaign to 2021 and to replicate the cold pool part of FESSTVaL in Hamburg under the name FESST@HH to make it compatible with home-office regulations.

\subsection{Experiment area}

Hamburg is the second largest city in Germany (population: 1.9 million; 2019) and is located in northern Germany $\left(53.5^{\circ} \mathrm{N}\right.$, $10.0^{\circ} \mathrm{E}$ ) about $80 \mathrm{~km}$ from the North Sea and the Baltic Sea. The FESST@HH measurement sites cover an area of $50 \mathrm{~km} \times 35 \mathrm{~km}$ that includes the urban center of Hamburg and its rural surroundings (Fig. 5). The station network consists of 82 APOLLO sites (Table 3) and 21 WXT sites (Table 4) that are randomly scattered over the domain with the tendency for a higher station density closer to the city center. The random arrangement results from the location of private gardens and of public facilities like schoolyards that could be used as measurement sites (see section 3.2). The average nearest-neighbor distance between all 103 measurement sites is $1.85 \pm 1.42 \mathrm{~km}$, whereas it is $1.93 \pm 1.41 \mathrm{~km}$ and $5.49 \pm 1.98 \mathrm{~km}$ for APOLLO and WXT, respectively. The measurement area is crossed by the Elbe river in southeast-northwest direction and is characterized by relatively flat terrain. While the Elbe valley is situated around sea level, the elevation north and south of it does not exceed about $80 \mathrm{~m}$ and $110 \mathrm{~m}$, respectively. The altitude of all measurement site lies between $1 \mathrm{~m}$ and $82 \mathrm{~m}$ above sea level with an average of $17 \mathrm{~m}$.

To characterize the environmental properties of the measurement sites, we apply the local climate zone (LCZ) framework introduced by Stewart and Oke (2012). This framework classifies the impact of surface structure, surface cover and human activity on the local thermal climate with the help of 17 standardized LCZ classes. All 103 FESST@HH sites fall into 15 different LCZ classes, which also includes combinations of classes to describe the heterogeneity within about $500 \mathrm{~m}$ around the station (Bechtel et al., 2015). The majority of sites (61) are situated in an open arrangement of low-rise buildings and scattered trees (LCZ 6; mixed in Fig. 5), while 24 sites, mostly near the city center, are located in the proximity of mid-rise and high-rise buildings, either in a compact or open arrangement ( $L C Z ~ 2,4$ and 5; urban). Each of the other occurring classes contain less than ten sites, which include natural environments (LCZ 9, A, B and D) and industrial areas with mostly paved surfaces (LCZ 8 and 10). 10 sites are situated near large water bodies like the Elbe river, the Alster lake, or channels (LCZ G).

\subsection{Implementation}

The installation of instruments started in late May 2020 and took about 3 weeks. The measurement period covered all three summer months and ended in early September 2020. The realization of the experiment was enabled by the support of many institutions and private landowners who provided permissions at short notice for using their premises as measurement sites. The different groups of landowners are indicated by two-letter acronyms as part of a unique site identifier code that also 
https://doi.org/10.5194/essd-2021-424

Preprint. Discussion started: 3 March 2022

(c) Author(s) 2022. CC BY 4.0 License.

(c) (i)

contains the site number and the installed instrument type $(\mathrm{a}=$ APOLLO, $\mathrm{w}=\mathrm{WXT})$. The majority of measurement stations were installed in private gardens and backyards (PG; Fig. 6a) as well as on the grounds of various institutions and clubs (OG). Further groups of sites include existing weather stations and sites of the Meteorological Institute (WS and MI), air quality observation sites of the Free and Hanseatic City of Hamburg (LM), grounds of the University of Hamburg (UH), and schoolyards (KB). A special characteristic of the latter group is that most of the respective APOLLO logger components are mounted at existing weather stations used for educational purposes and, therefore, exhibit lower temperature sensor heights $(\sim 1.8 \mathrm{~m})$ than the standard stations (Fig. 6b). Further deviations from the standard APOLLO installation include four loggers mounted on balconies (040UHa, 092PGa, 111OGa, and 113PGa; Fig. 6e) and two WXT stations installed on top of a container (017LMw; Fig. 6g) and on a roof-deck of the building of the Meteorological Institute (114UHw; Fig. 6h). Due to technical issues, minor changes to the instrumental set up had to be implemented during the measurement period with the replacement of one APOLLO (068OGa) and two WXT stations (048OGw and 114UHw) as well as the replacement of one APOLLO by a WXT station (083PGa).

Ensuring the implementation of FESST@HH was compatible with home-office not only affected the selection of measurement sites but also the maintenance strategy. Instead of a small team servicing the entire network, the maintenance work was shared between nearly 40 people. Private landowners, who provided measurement sites in their backyard, could also volunteer to regularly change the battery, check the data and upload it to a FTP server. Other stations located on public ground, schoolyards or industrial premises were serviced by colleagues living nearby. The main benefit of this maintenance strategy was that the collective effort kept the individual workload very low and promoted the continuous operation of the instruments, which eventually eased the execution of the experiment under challenging circumstances.

\section{Data processing}

The processing of the APOLLO and WXT station measurement data is a two-stage procedure. This study describes the published level 2 data format that contains quality-controlled data in a standardized format. In contrast, level 0 data are the raw data as directly produced by the instruments and level 1 data are homogenized data for preliminary analyses, but have not passed any quality checks.

\subsection{Level 0 data}

The raw measurement data are stored in ASCII files. The APOLLO data logger creates a new file at the start time, which contains the internal logger time, the GPS-synchronized time, the resistance readings of the NTC thermometer, the pressure readings of the BME280 module and status information at $1 \mathrm{~Hz}$ frequency. In contrast, new level $0 \mathrm{WXT}$ data files are created at midnight on a daily basis. Each line in the files consists of a GPS-synchronized time stamp and the measurement telegram of a specific sensor module, whereas each module sends data at $10 \mathrm{~s}$ intervals. 
https://doi.org/10.5194/essd-2021-424

Preprint. Discussion started: 3 March 2022

(c) Author(s) 2022. CC BY 4.0 License.

(c) (i)

\subsection{Level 1 data}

Measurement data, which have passed the first processing step, are called level 1 data. At this stage, basic standardization procedures are performed to allow for easy access to the data for preliminary analyses, but not quality checks. Most importantly, this includes the correction and homogenization of the data time stamps. For the APOLLO data, the internal logger time is corrected with its deviation from the most recent valid GPS time stamp that is logged once per hour. Data for missing time steps are filled with placeholder values $(\mathrm{NaN})$. Furthermore, daily files are created by splitting multi-day files and merging sub-daily files. In case of the WXT data, all time stamps are moved to a regular $10 \mathrm{~s}$ time grid. The measurement data itself are not manipulated, except for the APOLLO thermometer readings that are converted from resistance to temperature. For both station types, level 1 data are stored in a standard ASCII format.

\subsection{Level 2 data}

The purpose of the second processing level is to generate a standardized and quality-controlled data product that is ready to use for scientific analyses. Since the raw APOLLO measurements contain different kinds of erroneous data, which originate from technical issues of the logger or characteristics of the measurement site, we apply several quality checks and corrections to clean up the data. This processing step is not required for WXT data due to internal quality checks implemented by the manufacturer of the sensor. In total, less than $1 \%$ of the level 1 data fail the quality criteria and need to be removed. The correction procedure contains the following steps:

- removing erroneous temperature and pressure data outside plausible limits defined by $0 \leq T \leq 40^{\circ} \mathrm{C}$ and $950 \leq p \leq$ $1050 \mathrm{hPa}$, respectively;

- removing spikes in temperature (pressure) larger than $\Delta T=0.5 \mathrm{~K}(\Delta p=1 \mathrm{hPa})$, where $\Delta T(\Delta p)$ denotes the absolute difference from the $30 \mathrm{~s}(60 \mathrm{~s})$ running median value. For the temperature data, spikes are only removed for phases of active WiFi connection, which produces the spikes;

- removing temperature data showing implausibly large differences from the current network mean value defined as $\mid T-$ $\bar{T} \mid>15 \mathrm{~K}$. For three stations with erroneous NTC temperature sensor (037UHa, 040UHa, 068OGa), a criterion of $\mid T-$ $\bar{T} \mid>2 \mathrm{~K}$ is applied and all data within a time window of $15 \mathrm{~min}$ before and after erroneous data are also removed;

- manually removing single periods of erroneous temperature and pressure measurements that are not filtered by the previous criteria. In case of station 039UHa, temperature measurements on more than 40 days are affected by the warm air outlet of a near by air conditioning facility and are manually removed;

- applying a $10 \mathrm{~s}$ running mean smoothing procedure on the temperature measurements of station 113PGa to account for an anomalously high noise level of the NTC sensor;

- correcting the individual biases of NTC temperature sensors. The biases are determined from a one week long calibration with respect to a reference WXT sensor $(114 \mathrm{UHw})$; 
https://doi.org/10.5194/essd-2021-424

Preprint. Discussion started: 3 March 2022

(c) Author(s) 2022. CC BY 4.0 License.

(c) (i)

Level 2 data are stored in the NetCDF4 data format (Eaton et al., 2017), while the naming of files, variables and attributes complies with the SAMD (Standardized Atmospheric Measurement Data) Product Standard (Lammert et al., 2018). Accordingly, all measurement data of the same variable and from the same type of instrument are merged and stored in daily files. The file header contains all relevant meta data describing the individual measurement sites, namely the station identifier, the station name, the geographic coordinates, the altitude above sea level, the sensor height above ground and the LCZ.

\section{Description of data set}

\subsection{Data availability}

The level 2 data set of FESST@HH covers the period from 1 June to 31 August 2020 (Fig. 7a). The average availability of valid temperature observations is $83.2 \%$ and $87.6 \%$ for all APOLLO and WXT stations, respectively. Since the 3 month period also includes the installation phase of the instruments during the first half of June, these numbers increase to $90.0 \%$ and $94.3 \%$ if only the period after 15 June is considered. During this period, the daily availability of APOLLO and WXT measurements is always larger than $82.6 \%$ and $90.0 \%$, respectively. Apart from the removed measurements affected by erroneous sensors and local site conditions, most of the data gaps in the APOLLO data are due to missing power supply of the loggers, either caused by technical issues related to the power bank batteries or insufficient maintenance. In only one case was a battery stolen. The higher stability of the power supply is also the reason for the generally higher availability of WXT data compared to APOLLO data.

\subsection{Weather conditions}

The weather conditions during the FESST@HH period covered the full range of a typical mid-latitude summer. The air temperature measured by the station network ranges between a minimum of $5.3^{\circ} \mathrm{C}$ on 13 July and a maximum of $35.6^{\circ} \mathrm{C}$ on 8 August (Fig. 7b). During the entire 92 day period, the maximum temperature exceeded $25^{\circ} \mathrm{C}$ on 41 days and $30^{\circ} \mathrm{C}$ on 16 days, including an exceptionally long period of 12 consecutive days with more than $30^{\circ} \mathrm{C}$ between 6 August and 17 August. In contrast, July was characterized by a phase of relatively cold temperatures with a maximum of above $25^{\circ} \mathrm{C}$ on only 6 days. Rainfall, defined as a daily rainfall accumulation of more than $1 \mathrm{~mm}$ at at least one WXT station of the network, was observed on half of the days from 1 June to 31 August (Fig. 7c). On 11 days, mostly between 27 June and 10 July, the median rainfall amount exceeded $5 \mathrm{~mm}$. A maximum daily accumulation of $28.2 \mathrm{~mm}$ was observed on 27 June when a strong convective event occurred.

\section{Observations of sub-mesoscale phenomena}

The goal of the FESST@HH experiment was to design and operate an observation network that is dense enough to investigate the structure of convective cold pools. However, the data set also contains information and potential scientific implications for further sub-mesoscale phenomena that we present here. 
https://doi.org/10.5194/essd-2021-424

Preprint. Discussion started: 3 March 2022

(c) Author(s) 2022. CC BY 4.0 License.

\subsection{Cold pools}

During the 3 month measurement period, 37 cold pool events occurred, defined by at least five stations satisfying the cold pool detection criterion introduced by Kirsch et al. (2021a), i. e., a local temperature drop of at least $2 \mathrm{~K}$ within 30 min associated with rainfall. To demonstrate the ability of the station network to capture the characteristics of a cold pool and to shed light on its internal structure, we present one case study.

On 10 August 2020 around 12:45 UTC, a strong and nearly stationary convective precipitation cell developed southeast of the city center. About $10 \mathrm{~min}$ later, the formation of a cold pool became evident from a rapid cooling of the surface-layer air masses. Fig. 8 illustrates the evolution of the cold pool with snapshots of the temperature perturbations relative to the pre-event state observed by the station network. About $20 \mathrm{~min}$ after initiation of the convective cell, the cold pool exhibited a temperature perturbation of up to $-8 \mathrm{~K}$ within an area of less than $10 \mathrm{~km}$ in diameter (Fig. 8a). After another $20 \mathrm{~min}$, the cold pool deepened to about $-11 \mathrm{~K}$ and expanded to a size of roughly $10 \mathrm{~km} \times 20 \mathrm{~km}$ (Fig. 8b). This process continued until around 14:00 UTC when the cold pool reached its maximum temperature perturbation of about $-12 \mathrm{~K}$ and a diameter of nearly $30 \mathrm{~km}$, whereas the northeastern parts of the cold pool were outside of the network (Fig. 8d). The associated near-surface wind field observed by the WXT weather stations indicated a strong divergent flow at the cold pool center, especially during the early stages of its life cycle (Fig. 8a and b). Consistent with expected characteristics of a cold pool, the radial expansion of the cold air masses during the later stages was also present in the wind observations, predominantly southwest of the cold pool center (Fig. 8c and d).

The time series of temperature measurements at selected stations of the network provide further insights into the spatial structure and life cycle of the cold pool (Fig. 9a). APOLLO station Luxweg (104PGa) near the cold pool origin experienced an initial temperature drop of approximately $8 \mathrm{~K}$ within $5 \mathrm{~min}$ that continued at a slower rate afterwards and reached its maximum perturbation of $-12 \mathrm{~K}$ after one hour. This value is on the order of strongest temperature perturbations expected during cold pool passages in Hamburg (Kirsch et al., 2021a). The readings of the stations Ochsenwerder Norderdeich (082PGa) and Obsthof Lehmbeck (054OGa), located $4 \mathrm{~km}$ and $12 \mathrm{~km}$ further south, respectively, reveal that the maximum cooling decreases to about one-third away from the center, which suggests a highly heterogeneous temperature structure inside the cold pool. Since the site Luftmessnetz Habichtstraße (018LMa), situated northwest of the cold pool center, experienced no cooling at all, the cold pool produced a temperature gradient of $12 \mathrm{~K}$ within a distance of $11 \mathrm{~km}$. This result is in line with the findings of van den Heever et al. (2021) who report a variation of near-surface cold pool properties on scales between $\mathcal{O}(100) \mathrm{m}$ and $\mathcal{O}(1) \mathrm{km}$. The time lags between the cooling signals observed on the southern side of the cold pool also allow us to estimate its propagation velocity. Based on time lags of about $15 \mathrm{~min}$ and $50 \mathrm{~min}$ for travel distances of $3.9 \mathrm{~km}$ (104PGa-082PGa) and $11.9 \mathrm{~km}$ (104PGa$054 \mathrm{PGa}$ ), respectively, the velocity is of about $4 \mathrm{~m} \mathrm{~s}^{-1}$. This value lies in the expected range (Borque et al., 2020), considering that the parent precipitation cell was almost stationary and, therefore, did not superimpose the buoyancy-driven propagation of the cold air.

The accompanying air pressure measurements at the four selected sites confirm that the negative temperature perturbation of the cold pool is associated with a typical hydrostatic pressure rise (Fig. 9b). However, the positive pressure perturbation was well-pronounced only at station 104PGa, while the amplitudes were not proportional to the strength of the corresponding 
https://doi.org/10.5194/essd-2021-424

Preprint. Discussion started: 3 March 2022

(c) Author(s) 2022. CC BY 4.0 License.

(c) (i)

cooling signals. The pressure signal at station 104PGa also experienced rapid fluctuations of about $1 \mathrm{hPa}$ that were not apparent at the three other sites. Although an in-depth investigation of such effects lies beyond the scope of this study, this may indicate that the spatial structure of a cold pool differs between temperature and pressure and that mechanisms other than the hydrostatic cooling control the pressure signal near the center.

\subsection{Urban heat island}

The FESST@HH data set is well suited for studying urban climate effects as the station network covers both the city center and its rural surrounding. Stations near the city center record weather conditions with urban modifications, whereas rural stations provide undisturbed references. Focusing on air temperature, we define the urban modification $\Delta T_{\text {city }}$ as the difference between the locally observed air temperature and the undisturbed, natural temperature $T_{\text {nat }}$, determined exclusively by largescale weather conditions. On scales of $\mathcal{O}(10) \mathrm{km}$ without orography, it is reasonable to assume that $T_{\text {nat }}$ varies only linearly in space. We estimate the mean and the slope of this linear temperature field with a regression using all stations in weakly sealed environments, i.e., all stations with a maximum sealing up to open low-rise (LCZ 6). The mean diurnal cycle of $\Delta T_{\text {city }}$ features a step function at almost all stations (Fig. 10a). During daytime, the urban effects are small and $\Delta T_{\text {city }}$ is close to zero everywhere. In contrast, during nighttime, predominantly between 21 and $3 \mathrm{UTC}, \Delta T_{\text {city }}$ reaches a constant level at all stations, which largely reflects the well-known nocturnal urban heat island effect. For example, the most central station Wetterstation HafenCity (010WSa; orange in Fig. 10a) is almost $2.5 \mathrm{~K}$ warmer than estimated $T_{\text {nat }}$ and the most rural site Obsthof Schuback $(055 \mathrm{OGw})$ is even $1.5 \mathrm{~K}$ colder than the reference. The spatial pattern of the mean nocturnal urban heat excess is in agreement with the typical heat island structure featuring largest values close to the city center (Fig. 10b). Further analysis of individual days (not shown) provides indication that the advection of the heat island effect causes downwind heat plumes to form, which affect specific outskirts depending on the prevailing wind direction.

\subsection{Turbulent temperature fluctuations}

The NTC temperature sensor of the APOLLO station responds rapidly to air temperatures fluctuations. The recorded time series with a sampling rate of $1 \mathrm{~Hz}$ partly resolves temperature eddies related to turbulent sensible heat fluxes. The high frequency temperature fluctuation expressed by the standard deviation of temperature readings within 1 min intervals, $\sigma_{\mathrm{T}}$, features a well-pronounced diurnal cycle (Fig. 11a). During nighttime, $\sigma_{\mathrm{T}}$ is close to $0.05 \mathrm{~K}$ at all stations, which most likely resembles the noise level of the instruments. However, at daytime, $\sigma_{\mathrm{T}}$ is well above that noise level and follows the common diurnal cycle of net radiation or sensible heat flux at the surface. Turbulent fluxes are strongly determined by the local surface condition like albedo, sealing or vegetation cover. Likewise, the differences in the diurnal cycle of $\sigma_{\mathrm{T}}$ can be explained by local surface conditions: the station Stadtteilschule Blankenese $(033 \mathrm{KBa})$ at a schoolyard next to a sportsground (low albedo, no evapotranspiration) with free insolation exhibits the highest temperature variability. High values also occur at the schoolyard of station Schule Redder (036KBa) but are shifted and limited to morning hours due to a building west of the station casting

310 a shadow and reflecting sunlight. Even more extreme, buildings shade the station Luftmessnetz Rothenburgsort (020LMa) almost the whole day except during the late afternoon. The lowest temperature variance is observed at station Uni Sternwarte 
https://doi.org/10.5194/essd-2021-424

Preprint. Discussion started: 3 March 2022

(c) Author(s) 2022. CC BY 4.0 License.

(c) (i)

(043UHa), the only station below tall trees. The heat exchange within the tree canopy effectively reduced the energy exchange at the ground.

The relation between surface heat exchange and temperature variability is also directly confirmed by correlating the net radiation observed at the Hamburg weather mast reference site (Bruemmer et al., 2012) with $\sigma_{\mathrm{T}}$ at the neighboring APOLLO station Wetterstation Zollamt (011WSa) located about $750 \mathrm{~m}$ away (Fig. 11b). Values of $\sigma_{\mathrm{T}}$ lower than $0.75 \mathrm{~K}$ are strongly correlated to situations where the net radiation is close to zero. Increasing variance beyond this threshold is mostly explained by increasing net radiation $\left(r^{2}=0.77\right)$. Instead of the sensible heat flux, we use the net radiation for this analysis to minimize the influence of land surface differences between the two sites (pasture at Wetterstation Zollamt versus sealed area at Hamburg weather mast). Additional measurements on a test site show that the heating of the sensor shield by solar radiation does not impact $\sigma_{\mathrm{T}}$ (not shown). This finding supports our reasoning that the APOLLO stations capture turbulent temperature fluctuations that are mainly caused by the surface heat exchange in the near environment of the observation site.

\section{Summary and conclusions}

The FESST@HH field experiment took place in Hamburg (Germany) from June to August 2020 with the primary aim of illuminating the internal structure of convective cold pools that conventional observations miss. To this end, a dense network of 103 autonomously operating weather stations was installed over an area of $50 \mathrm{~km} \times 35 \mathrm{~km}$ with an average distance between the stations of $1.85 \mathrm{~km}$. The measurements were mainly conducted by 82 low-cost, custom-built APOLLO stations that were designed to sample the strong and rapid changes in air temperature and pressure associated with cold pools at $1 \mathrm{~s}$ resolution. Additional measurements of relative humidity, wind speed and precipitation at 10 s resolution were performed by 21 WXT weather stations based on commercial sensors.

The FESST@HH data set is unique not only with respect to its scientific potential for investigating sub-mesoscale atmospheric processes but also with respect to its implementation. The experiment was successfully conducted despite the exceptional circumstances caused by the COVID-19 pandemic, especially thanks to the short-notice support of local institutions and private landowners, who provided their ground as measurement sites and helped with the station maintenance. The low-cost and self-manufactured measurement instruments operated smoothly without any major technical problems, although they were never used in such a large number before. The good performance is reflected by an availability of quality-controlled data of more than $90 \%$ during the main observation period. Most importantly, a case study demonstrates that the network is capable of mapping the sharp horizontal temperature gradients produced by a convective cold pool and capturing its spatial footprint. Throughout its life cycle, the cold pool diameter grows from less than $10 \mathrm{~km}$ to nearly $30 \mathrm{~km}$, while its leading edge propagates at a velocity of about $4 \mathrm{~m} \mathrm{~s}^{-1}$ away from the center of convection. There is also evidence that the spatial variance of the corresponding pressure signals differs from the cooling signature and may indicate the presence of non-hydrostatic effects acting within the cold pool center. Furthermore, the data set is relevant for studies in urban meteorology as the dense temperature observations include information on the spatial structure of the nocturnal urban heat island as well as on the local surface heat exchange mirrored by high-frequency temperature fluctuations. 
https://doi.org/10.5194/essd-2021-424

Preprint. Discussion started: 3 March 2022

(c) Author(s) 2022. CC BY 4.0 License.

(c) (i)

The FESST@HH field experiment proves that it is possible to conduct observations that close the information gap left by conventional measurement networks. In addition, it highlights the real need for dense station networks that act like a magnifying glass for sub-mesoscale atmospheric processes. The use of a large number of low-cost instruments designed for a specific purpose has shown to be a feasible strategy to tailor a measurement network that is dense enough to shed light on previously unobserved scales. These data are scientifically valuable not only for a deeper understanding of cold pools and the convective life cycle, but also for the validation of hectometer-scale numerical simulations. Moreover, the data set leaves space for unexpected results and applications not yet anticipated. FESST@HH also exemplifies how a major community effort can ease the execution of a major scientific enterprise or - as in this case - make it possible at all. In this sense, FESST@HH has the potential to be a prototype for future field campaigns. It already provides a prove of concept for an extended investigation of cold pools and further sub-mesoscale boundary layer structures during the FESSTVaL 2021 experiment.

\section{Data availability}

The data set is available at https://doi.org/10.25592/UHHFDM.8973 (Kirsch et al., 2021b). The file size per day and measurement variable is about $25 \mathrm{MB}$ and $1.5 \mathrm{MB}$ for APOLLO and WXT data, respectively.

Author contributions. BK wrote the manuscript (except for sections 6.2 and 6.3), processed the data, performed the cold pool analyses, helped to design, assemble and test the instruments and to install and service the measurement stations. $\mathrm{CH}$ and DK conceptualized the idea for the experiment. RS designed, assembled and tested the APOLLO hardware and software. MO designed the components and technical infrastructure of the APOLLO and WXT stations and helped to service them. FA prepared sections 6.2 and 6.3 and performed the corresponding analyses, helped to design the instruments, plan the experiment and service the stations.

Competing interests. The authors declare that they have no conflict of interests.

Acknowledgements. We are grateful to Marco Clemens and Ingo Lange for heavily supporting the manufacturing, installation and maintenance of measurement stations and to Sarah Wiesner for planning and coordinating the field experiment. We thank Theresa Szyszka and Jan Moritz Witt for assembling the APOLLO logger main boards, manufacturing the components of the APOLLO and WXT stations and supporting their maintenance. For either helping with the installation and maintenance of stations or providing ground for measurement sites we are thankful to Sigrid and Werner Bock, Agnes Bornholdt, Frank Böttcher, Burghardt Brümmer, Stefan Bühler, Finn Burgemeister, Guido Cioni, Martin Claussen, Traute Crüger, Henning Dorff, Tobias Finn, Veronika Gayler, David Grawe, Akio Hansen, Anja Hermans, Tatiana Ilyina, Olaf Jäke, Markus Kilian, Stefan Kinne, Marlene and Reinhard Kirsch, Brita Kliemt, Hartmut Kock, Heike Konow, Sascha Krueck, Heiner Meier, Ulrike Niemeier and Luis Kornblueh, Peter Peitzner, Jon Petersen, Thomas Raddatz, Jule Radtke, Berinike Rappat, Florian Römer, Nicole and Steffen Rüeß, Rita Schierholz, Imke Schirmacher, Hauke Schmidt, Amelie Schmitt, Hauke Schulz, Constanze 
https://doi.org/10.5194/essd-2021-424

Preprint. Discussion started: 3 March 2022

(c) Author(s) 2022. CC BY 4.0 License.

(c) (1)

Seibert, Milica Stankovic, Claudia Timmreck and Hannes Thiemann, Karla Tomhawe, Bodo Voigt, Stefan Walter, Ralf Wedemann, Tobias Weiß, Susanne and Heinz-Dieter Wenck, Benjamin Will, Holger Witt, and Florian Ziemen. We also acknowledge the following institutions, schools, clubs and companies for allowing us to install measurement stations on their grounds: Hamburger Luftmessnetz, Universität Hamburg, Bundesanstalt für Wasserbau Hamburg, Deutscher Wetterdienst Niederlassung Hamburg, Drachenfreunde Winsen, Greenpeace Wilhelmsburg, Gut Karlshöhe, Gymnasium Rahlstedt, Halepaghen-Schule Buxtehude, Hamburger Aero-Club Boberg, Hamburger Bogenschützen Gilde, Hansa Sportverein Stöckte, Hochschule für Angewandte Wissenschaften Hamburg, Immanuel-Kant-Gymnasium Harburg, Obsthof Axel Schuback, Obsthof Lehmbeck, Overmeyer Landbaukultur, Restaurant Bobby Reich, Restaurant Fährhaus Tatenberg, Schule Redder Sasel, Segelclub Rhe Hamburg, Segelvereinigung Sinstorf, Stadtteilschule Blankenese, Stadtteilschule Eidelstedt, Stadtteilschule Meiendorf, Suntrace, Tennisclub Eichtalpark, and TSV Holm.

This research was carried out in the Hans Ertel Center for Weather Research (HErZ). This German research network of universities, research institutions, and the German Weather Service (DWD) is funded by the BMVI (Federal Ministry of Transport and Digital Infrastructure).

BK is thankful to Jochem Marotzke and Dallas Murphy for providing valuable tips on the writing style and structure of the manuscript and to Arjun Kumar for proofreading. 
https://doi.org/10.5194/essd-2021-424

Preprint. Discussion started: 3 March 2022

(c) Author(s) 2022. CC BY 4.0 License.

(c) (i)

\section{References}

Comparison of evaporation and cold pool development between single-moment and multimoment bulk microphysics schemes in idealized simulations of tornadic thunderstorms, Mon. Weather Rev., 138, https://doi.org/10.1175/2009MWR2956.1.

Basara, J. B., Illston, B. G., Fiebrich, C. A., Browder, P. D., Morgan, C. R., McCombs, A., Bostic, J. P., McPherson, R. A., Schroeder, A. J., and Crawford, K. C.: The Oklahoma City Micronet, Meteorol. Appl., 18, 252-261, https://doi.org/10.1002/MET.189, 2011.

Bechtel, B., Alexander, P. J., Böhner, J., Ching, J., Conrad, O., Feddema, J., Mills, G., See, L., and Stewart, I.: Mapping local climate zones for a worldwide database of the form and function of cities, ISPRS Int. J. Geo-Inf., 4, 199-219, https://doi.org/10.3390/ijgi4010199, 2015.

Borque, P., Nesbitt, S. W., Trapp, R. J., Lasher-Trapp, S., and Oue, M.: Observational study of the thermodynamics and morphological characteristics of a midlatitude continental cold pool event, Mon. Weather Rev., 148, 719-737, https://doi.org/10.1175/MWR-D-19-0068.1, 2020.

Bosch: BME280 data sheet, version 1.9, https://www.bosch-sensortec.com/media/boschsensortec/downloads/datasheets/bst-bme280-ds002. pdf, accessed on 14 January 2021, 2020.

Bruemmer, B., Lange, I., and Konow, H.: Atmospheric boundary layer measurements at the 280 m high Hamburg weather mast 1995-2011: Mean annual and diurnal cycles, Meteorol. Z., 21, 319-335, https://doi.org/10.1127/0941-2948/2012/0338, 2012.

Bryan, G. H., Wyngaard, J. C., and Fritsch, J. M.: Resolution requirements for the simulation of deep moist convection, Mon. Weather Rev., 131, 2394-2416, https://doi.org/10.1175/1520-0493(2003)131<2394:RRFTSO>2.0.CO;2, 2003.

Crameri, F.: Scientific colour maps, version 7.0.1, https://doi.org/10.5281/zenodo.1243862, 2018.

Crameri, F., Shephard, G. E., and Heron, P. J.: The misuse of colour in science communication, Nat. Commun., 11, 5444, https://doi.org/10.1038/s41467-020-19160-7, 2020.

Eaton, B., Gregory, J., Drach, B., Taylor, K., Hankin, S., Blower, J., Caron, J., Signell, R., Bentley, P., Rappa, G., Höck, H., Pamment, A., Juckes, M., and Raspaud, M.: NetCDF Climate and Forecast (CF) Metadata Conventions version 1.7, p. 156, https://cfconventions.org/ Data/cf-conventions/cf-conventions-1.7/cf-conventions.pdf, accessed on 14 January 2021, 2017.

Engerer, N. A., Stensrud, D. J., and Coniglio, M. C.: Surface characteristics of observed cold pools, Mon. Weather Rev., 136, 4839-4849, https://doi.org/10.1175/2008MWR2528.1, 2008.

Feng, Z., Hagos, S., Rowe, A. K., Burleyson, C. D., Martini, M. N., and Szoeke, S. P. D.: Mechanisms of convective cloud organization by cold pools over tropical warm ocean during the AMIE/DYNAMO field campaign, J. Adv. Model Earth Sy., 7, 357-381, https://doi.org/10.1002/2014MS000384, 2015.

Goff, R. C.: Vertical structure of thunderstorm outflows, Mon. Weather Rev., 104, 1429-1440, https://doi.org/10.1175/15200493(1976)104<1429:VSOTO>2.0.CO;2, 1976.

Grant, L. D. and Heever, S. C. v. d.: Cold pool dissipation, J. Geohphys. Res.-Atmos., 121, 1138-1155, https://doi.org/10.1002/2015JD023813, 2016.

Hirt, M., Craig, G. C., Schäfer, S. A. K., Savre, J., and Heinze, R.: Cold-pool-driven convective initiation: using causal graph analysis to determine what convection-permitting models are missing, Q. J. Roy. Meteor. Soc., 146, 2205-2227, https://doi.org/10.1002/QJ.3788, 2020.

Khairoutdinov, M. and Randall, D.: High-resolution simulation of shallow-to-deep convection transition over land, J. Atmos. Sci., 63, 34213436, https://doi.org/10.1175/JAS3810.1, 2006. 
https://doi.org/10.5194/essd-2021-424

Preprint. Discussion started: 3 March 2022

(c) Author(s) 2022. CC BY 4.0 License.

(c) (i)

Kirchengast, G., Kabas, T., Leuprecht, A., Bichler, C., and Truhetz, H.: WegenerNet: A pioneering high-resolution network for monitoring weather and climate, Bull. Am. Meteorol. Soc., 95, 227-242, https://doi.org/10.1175/BAMS-D-11-00161.1, 2014.

Kirsch, B., Ament, F., and Hohenegger, C.: Convective cold pools in long-term boundary layer mast observations, Mon. Weather Rev., 149, 811-820, https://doi.org/10.1175/MWR-D-20-0197.1, 2021a.

Kirsch, B., Hohenegger, C., Klocke, D., Senke, R., Offermann, M., and Ament, F.: FESST@HH meteorological network measurements, version v00, https://doi.org/10.25592/UHHFDM.8973, 2021 b.

Kurowski, M. J., Suselj, K., Grabowski, W. W., and Teixeira, J.: Shallow-to-deep transition of continental moist convection: Cold pools, surface fluxes, and mesoscale organization, J. Atmos. Sci., 75, 4071-4090, https://doi.org/10.1175/JAS-D-18-0031.1, 2018.

Lammert, A., Grützun, V., and Stamnas, E.: The SAMD product standard (Standardized Atmospheric Measurement Data), https://doi.org/10.5281/ZENODO.1741364, 2018.

Li, Z., Zuidema, P., Zhu, P., and Morrison, H.: The sensitivity of simulated shallow cumulus convection and cold pools to microphysics, J. Atmos. Sci., 72, 3340-3355, https://doi.org/10.1175/JAS-D-14-0099.1, 2015.

Madhavan, B. L., Kalisch, J., and Macke, A.: Shortwave surface radiation network for observing small-scale cloud inhomogeneity fields, Atmos. Meas. Tech., 9, 1153-1166, https://doi.org/10.5194/AMT-9-1153-2016, 2016.

Markowski, P. M., Straka, J. M., and Rasmussen, E. N.: Direct surface thermodynamic observations within the rearflank downdrafts of nontornadic and tornadic supercells, Mon. Weather Rev., 130, 1692-1721, https://doi.org/10.1175/15200493(2002)130<1692:DSTOWT>2.0.CO;2, 2002.

440 Mueller, C. K. and Carbone, R. E.: Dynamics of a thunderstorm outflow, J. Atmos. Sci., 44, 1879-1898, https://doi.org/10.1175/15200469(1987)044<1879:DOATO>2.0.CO;2, 1987.

Schlemmer, L. and Hohenegger, C.: The formation of wider and deeper clouds as a result of cold-pool dynamics, J. Atmos. Sci., 71, 28422858, https://doi.org/10.1175/JAS-D-13-0170.1, 2014.

Stevens, B., Acquistapace, C., Hansen, A., Heinze, R., Klinger, C., Klocke, D., Rybka, H., Schubotz, W., Windmiller, J., Adamidis, P., Arka, I., Barlakas, V., Biercamp, J., Brueck, M., Brune, S., Buehler, S. A., Burkhardt, U., Cioni, G., Costa-Suros, M., Crewell, S., Crueger, T., Deneke, H., Friederichs, P., Henken, C. C., Hohenegger, C., Jacob, M., Jakub, F., Kalthoff, N., Koehler, M., van Laar, T. W., Li, P., Loehnert, U., Macke, A., Madenach, N., Mayer, B., Nam, C., Naumann, A. K., Peters, K., Poll, S., Quaas, J., Roeber, N., Rochetin, N., Scheck, L., Schemann, V., Schnitt, S., Seifert, A., Senf, F., Shapkalijevski, M., Simmer, C., Singh, S., Sourdeval, O., Spickermann, D., Strandgren, J., Tessiot, O., Vercauteren, N., Vial, J., Voigt, A., and Zaengl, G.: The Added Value of Large-eddy and Storm-resolving Models for Simulating Clouds and Precipitation, J. Meteorol. Soc. Jpn., 98, 395-435, https://doi.org/10.2151/JMSJ.2020-021, 2020.

Stewart, I. D. and Oke, T. R.: Local climate zones for urban temperature studies, Bull. Am. Meteorol. Soc., 93, 1879-1900, https://doi.org/10.1175/BAMS-D-11-00019.1, 2012.

Szoeke, S. P. D., Skyllingstad, E. D., Zuidema, P., and Chandra, A. S.: Cold pools and their influence on the tropical marine boundary layer, J. Atmos. Sci., 74, 1149-1168, https://doi.org/10.1175/JAS-D-16-0264.1, 2017.

TE Connectivity: High humidity environments mini probe (MRBD), https://www.te.com/commerce/DocumentDelivery/DDEController? Action=showdoc\&DocId=Data+Sheet\%7FMRBD_10K3MRBD1\%7FA\%7Fpdf\%7FEnglish\%7FENG_DS_MRBD_10K3MRBD1_A. pdf\%7FGA10K3MRBD1, accessed on 7 October 2021, 2015.

Terai, C. R. and Wood, R.: Aircraft observations of cold pools under marine stratocumulus, Atmos. Chem. Phys., 13, 9899-9914, https://doi.org/10.5194/ACP-13-9899-2013, 2013. 
https://doi.org/10.5194/essd-2021-424

Preprint. Discussion started: 3 March 2022

(c) Author(s) 2022. CC BY 4.0 License.

(c) (1)

460 Tompkins, A. M.: Organization of tropical convection in low vertical wind shears: The role of cold pools, J. Atmos. Sci., 58, 1650-1672, https://doi.org/10.1175/1520-0469(2001)058<1650:OOTCIL>2.0.CO;2, 2001.

Torri, G., Kuang, Z., and Tian, Y.: Mechanisms for convection triggering by cold pools, Geophys. Res. Lett., 42, 1943-1950, https://doi.org/10.1002/2015GL063227, 2015.

Vaisala: Weather Transmitter WXT530 Series user guide, https://www.vaisala.com/sites/default/files/documents/ WXT530-User-Guide-in-English-M211840EN-E.pdf, accessed on 14 January 2021, 2020.

van den Heever, S. C., Grant, L. D., Freeman, S. W., Marinescu, P. J., Barnum, J., Bukowski, J., Casas, E., Drager, A. J., Fuchs, B., Herman, G. R., Hitchcock, S. M., Kennedy, P. C., Nielsen, E. R., Park, J. M., Rasmussen, K., Razin, M. N., Riesenberg, R., Dellaripa, E. R., Slocum, C. J., Toms, B. A., and van den Heever, A.: The Colorado State University Convective CLoud Outflows and UpDrafts Experiment (C3LOUD-Ex), Bull. Am. Meteorol. Soc., 102, E1283-E1305, https://doi.org/10.1175/BAMS-D-19-0013.1, 2021. 
https://doi.org/10.5194/essd-2021-424

Preprint. Discussion started: 3 March 2022

(c) Author(s) 2022. CC BY 4.0 License.

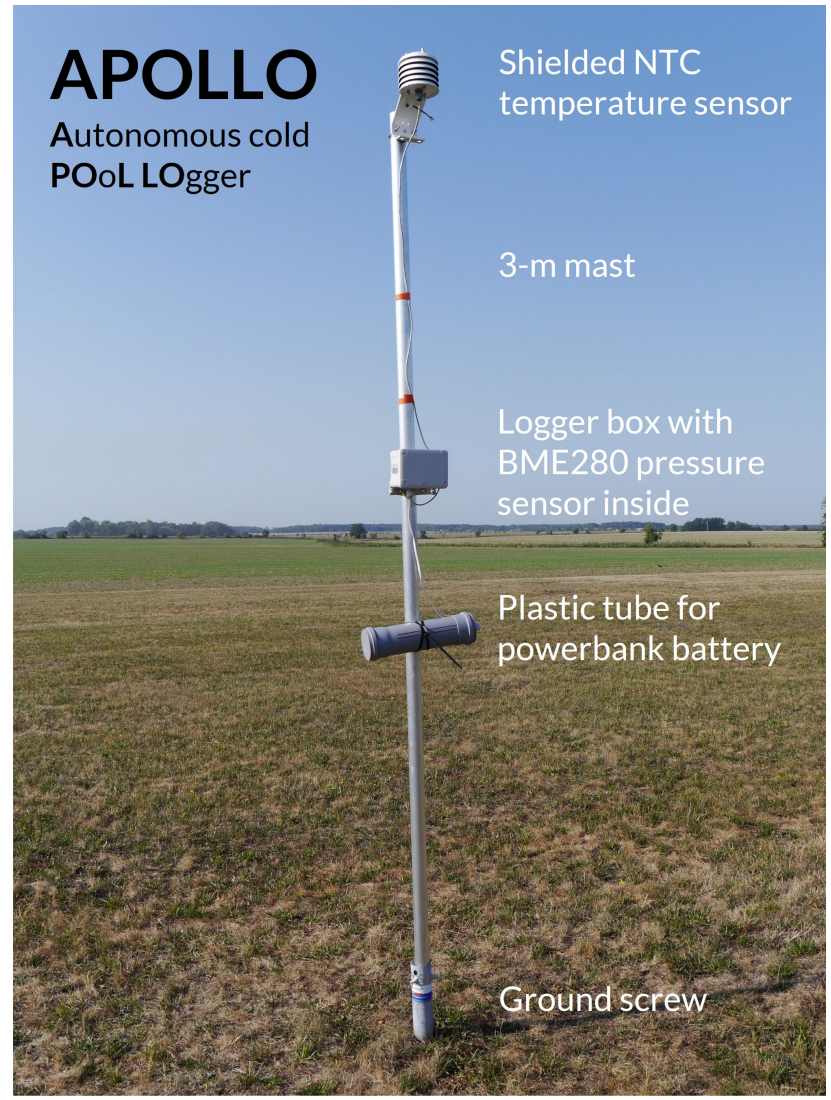

Figure 1. Components of APOLLO station. 
https://doi.org/10.5194/essd-2021-424

Preprint. Discussion started: 3 March 2022

(c) Author(s) 2022. CC BY 4.0 License.

(c) (i)


Figure 2. (a) NTC thermometer with scale for reference, (b) logger main board of APOLLO station. Marked are the micro controller board (1), digital air pressure sensor BME280 (2), micro-SD memory card (3), GPS receiver module (4), LoRa module (5) and pressure counterbalance valve (6). 
https://doi.org/10.5194/essd-2021-424

Preprint. Discussion started: 3 March 2022

(c) Author(s) 2022. CC BY 4.0 License.

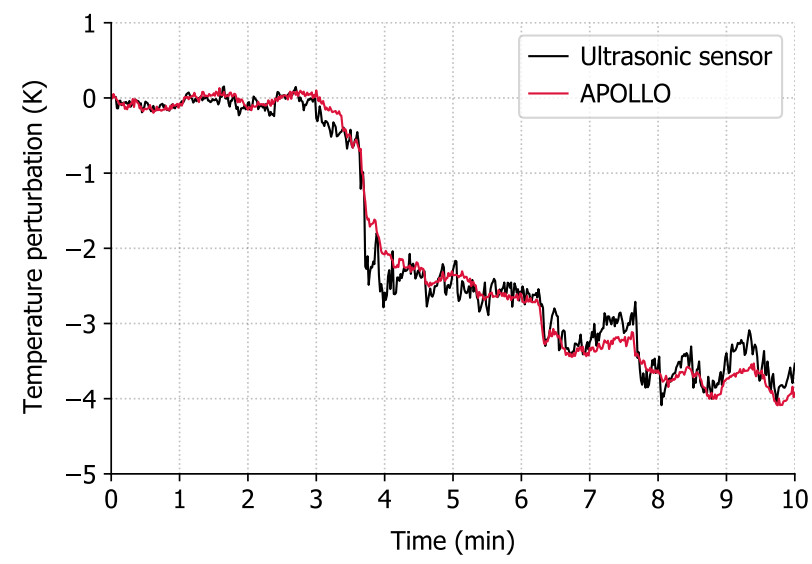

Figure 3. Air temperature perturbation observed by co-located ultrasonic sensor and APOLLO station during a cold pool event at the Meteorological Observatory Lindenberg (eastern Germany) on 26 August 2019. The readings of the ultrasonic sensor are $1 \mathrm{~s}$ averages of $20 \mathrm{~Hz}$ acoustic temperature measurements by an ultrasonic anemometer. 
https://doi.org/10.5194/essd-2021-424

Preprint. Discussion started: 3 March 2022

(c) Author(s) 2022. CC BY 4.0 License.

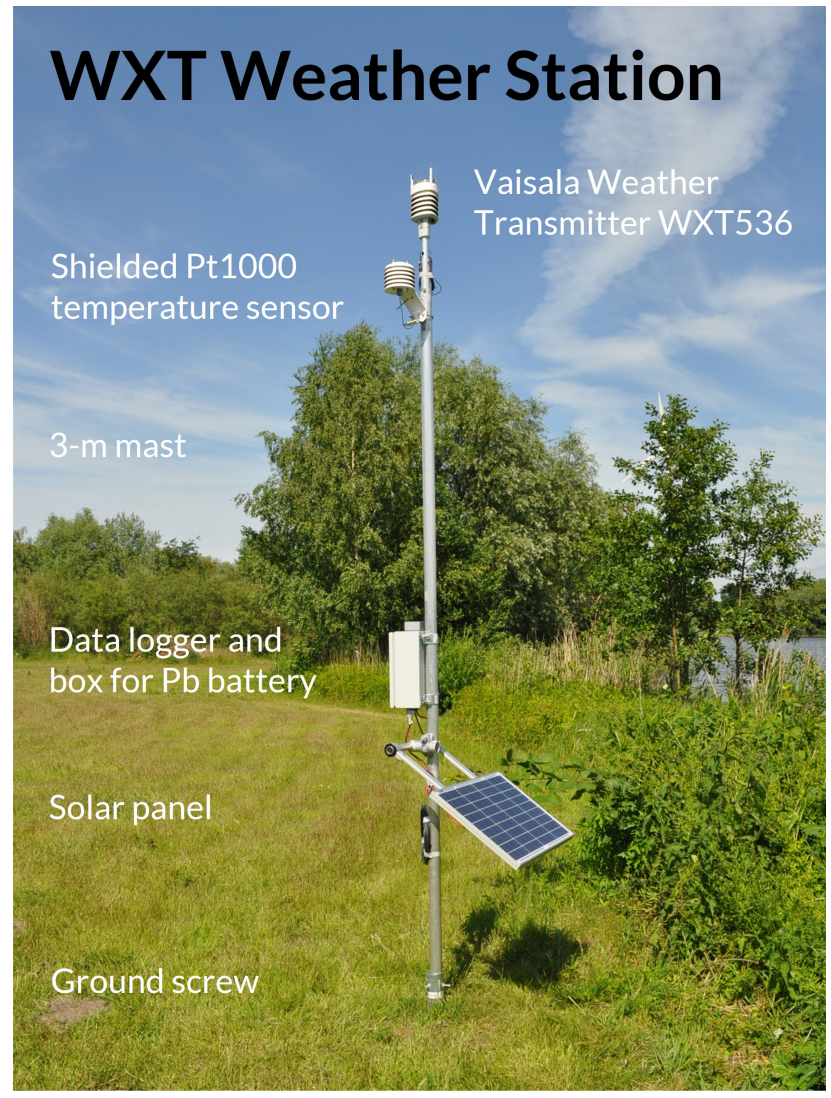

Figure 4. Components of WXT weather station. 


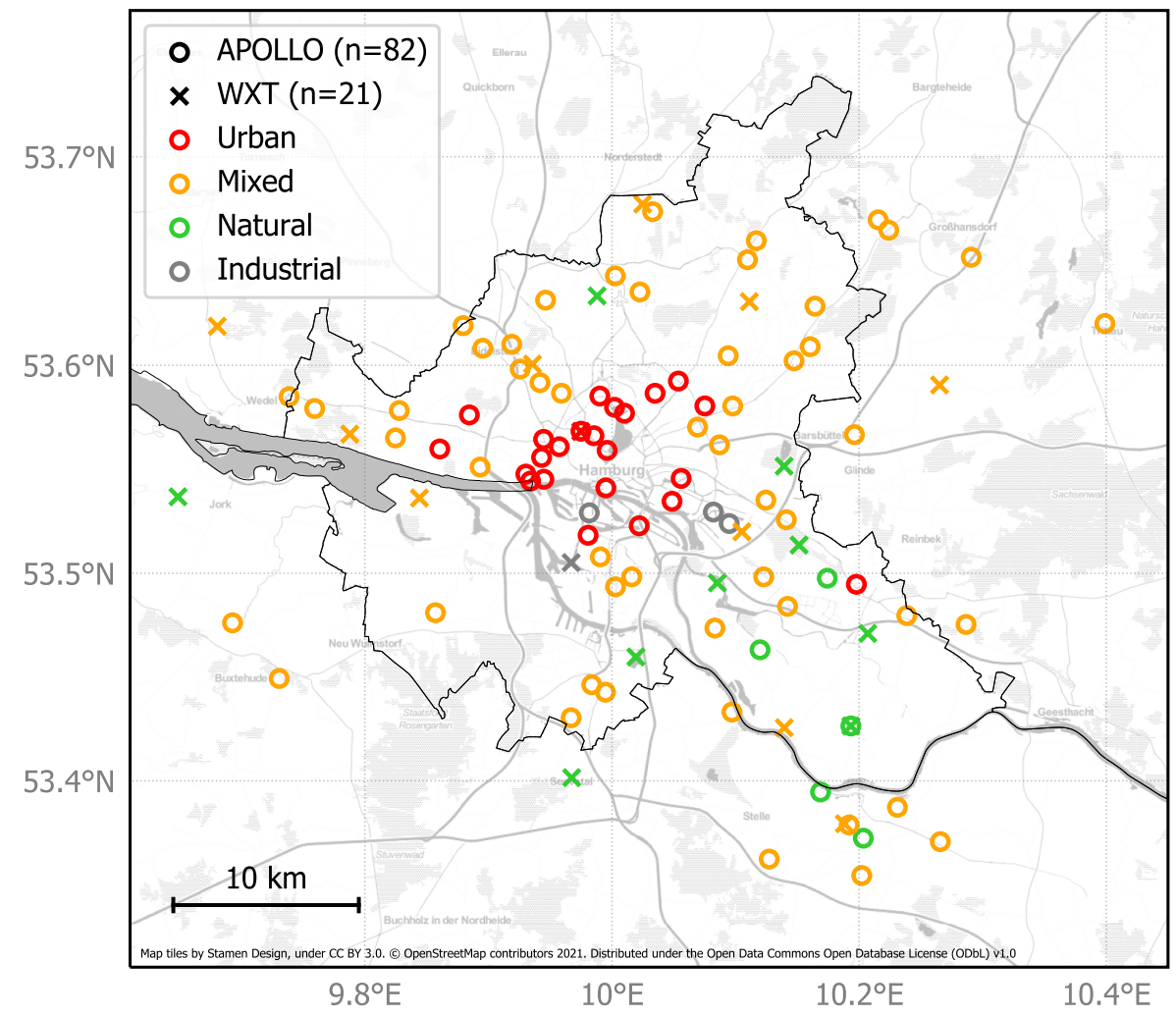

Figure 5. Map of APOLLO and WXT weather stations forming the FESST@HH network. Colors indicate environmental conditions of measurement sites grouped into urban (local climate Zone 2, 4 or 5), mixed (LCZ 6), natural (LCZ 9, B or D) and industrial (LCZ 8 or 10) following the framework of Stewart and Oke (2012). For stations falling into two LCZs, only the predominant sub-class is considered. Black lines mark the city limits of Hamburg. 
https://doi.org/10.5194/essd-2021-424

Preprint. Discussion started: 3 March 2022

(c) Author(s) 2022. CC BY 4.0 License.
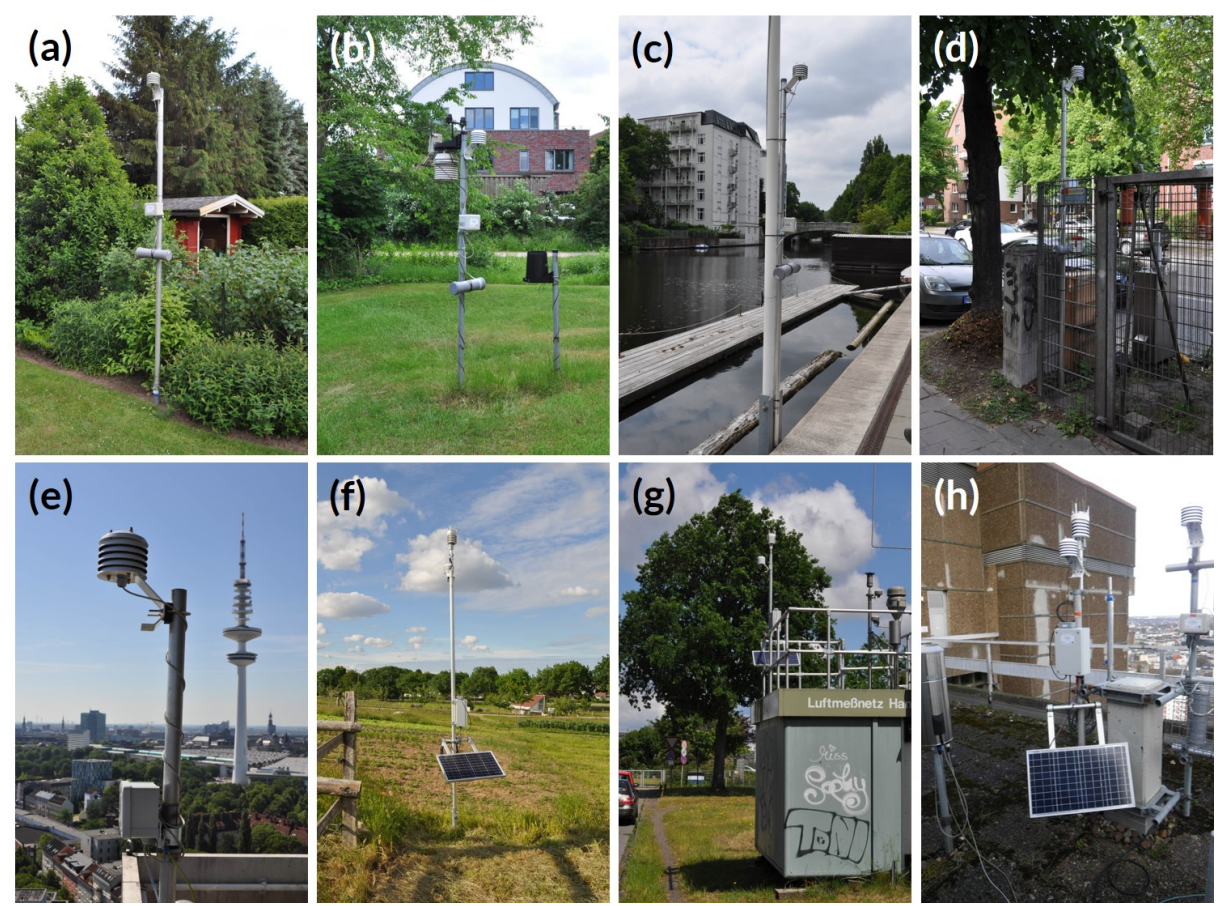

Figure 6. Examples of instrument installations during FESST @ HH: APOLLO station (a) as the standard installation in a private garden, (b) attached to an existing weather station on a schoolyard, (c) on a boat landing stage at a channel, (d) on an air quality observation site at a public road, (e) on the balcony of the building of the Meteorological Institute, and WXT weather station (f) as the standard installation on an agricultural field, (g) on top of a container, and (h) on the roof-deck of the building of the Meteorological Institute. 
https://doi.org/10.5194/essd-2021-424

Preprint. Discussion started: 3 March 2022

(c) Author(s) 2022. CC BY 4.0 License.

(c) (i)
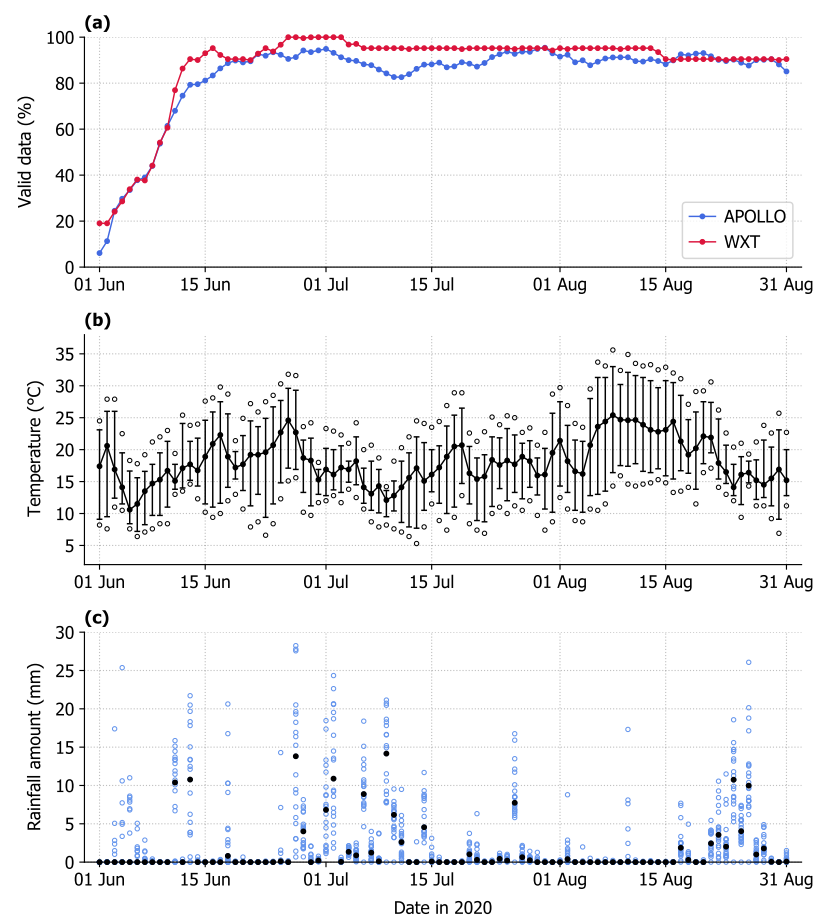

Figure 7. FESST@HH level 2 data from 1 June to 31 August 2020: (a) Daily mean fraction of valid temperature observations over all APOLLO and WXT stations, (b) daily median (filled dots), $5 \%$-quantile and 95\%-quantile (whiskers) and minimum and maximum (open circles) of all WXT air temperature observations, (c) individual accumulated rainfall amount at all WXT stations (open circles). Filled dots mark the daily median. 
(a) 13:05 UTC

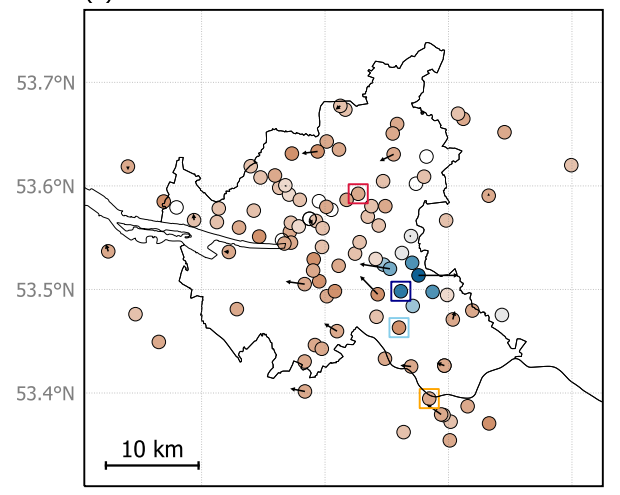

(c) 13:45 UTC

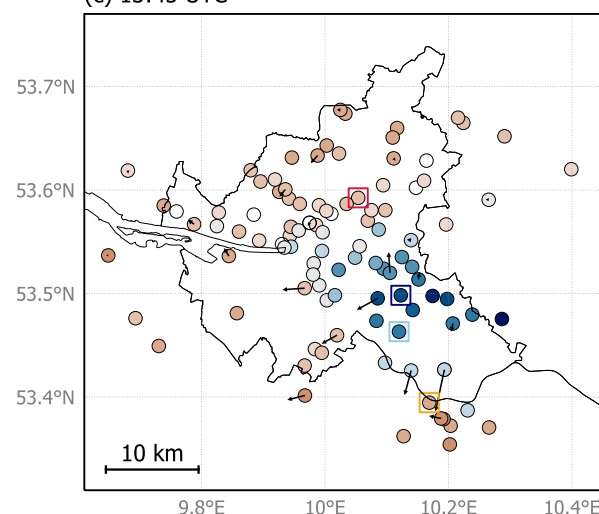

(b) $13: 25$ UTC

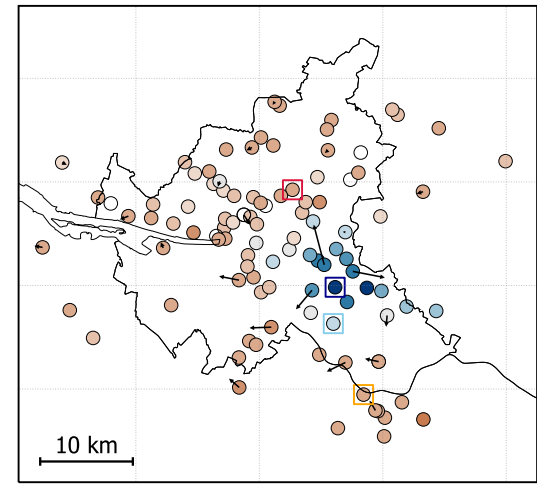

(d) 14:05 UTC

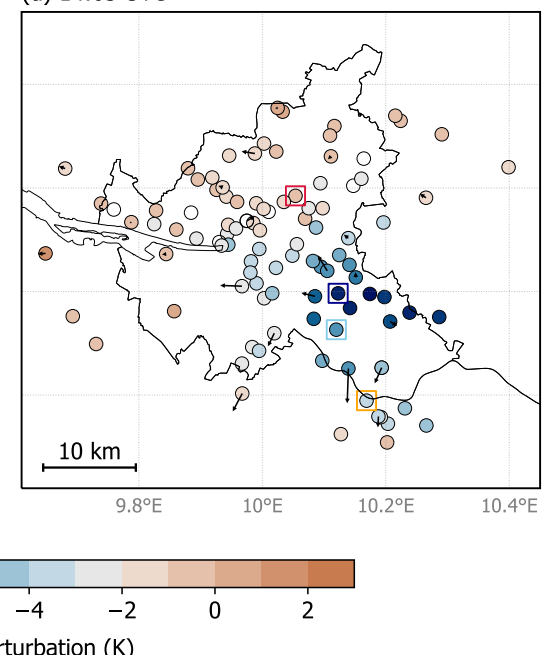

Figure 8. Perturbation in air temperature since 12:30 UTC from (a) 13:05 UTC to (d) 14:05 UTC observed by APOLLO and WXT stations during a cold pool event on 10 August 2020. Bluish colors mark stations inside the cold pool, defined by a temperature perturbation smaller than -2 K (color map by Crameri (2018); Crameri et al. (2020)). Black arrows indicate instantaneous wind speed and direction observed by WXT stations. Length of reference arrow refers to $5 \mathrm{~m} \mathrm{~s}^{-1}$ wind speed. The four highlighted stations refer to the respective data illustrated in Fig. 9. 
https://doi.org/10.5194/essd-2021-424

Preprint. Discussion started: 3 March 2022

(c) Author(s) 2022. CC BY 4.0 License.

(c) (i)
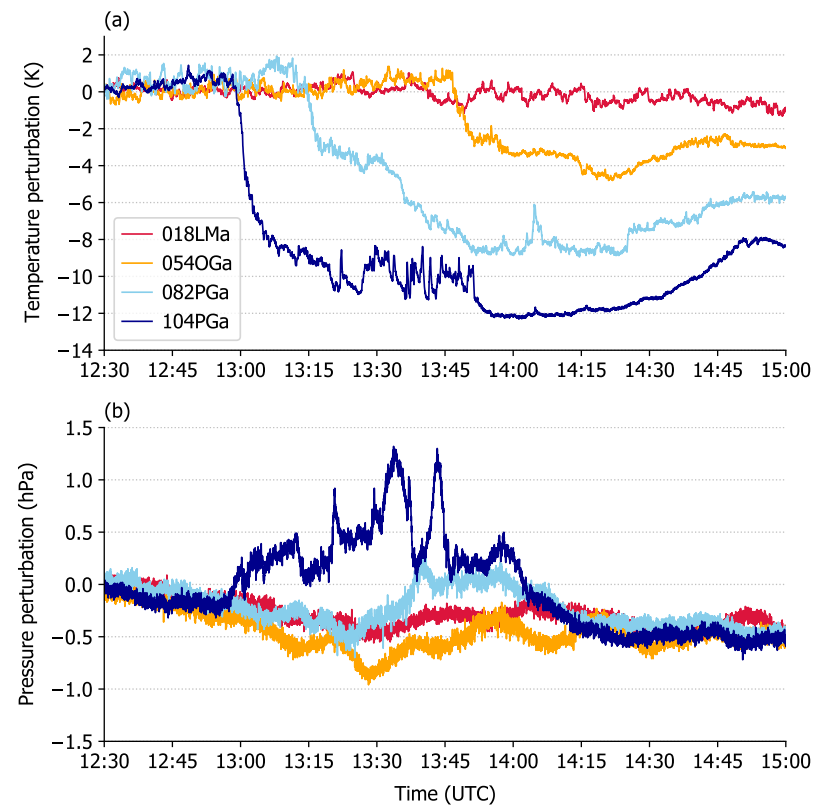

Figure 9. Perturbation in (a) air temperature and (b) pressure since 12:30 UTC observed by the four selected APOLLO stations Luftmessnetz Habichtstraße (018LMa), Obsthof Lehmbeck (054OGa), Ochsenwerder Norderdeich (082PGa) and Luxweg (104PGa) during a cold pool event on 10 August 2020. Locations of the stations are also highlighted in Fig. 8. 
https://doi.org/10.5194/essd-2021-424

Preprint. Discussion started: 3 March 2022

(c) Author(s) 2022. CC BY 4.0 License.

(c) (i)
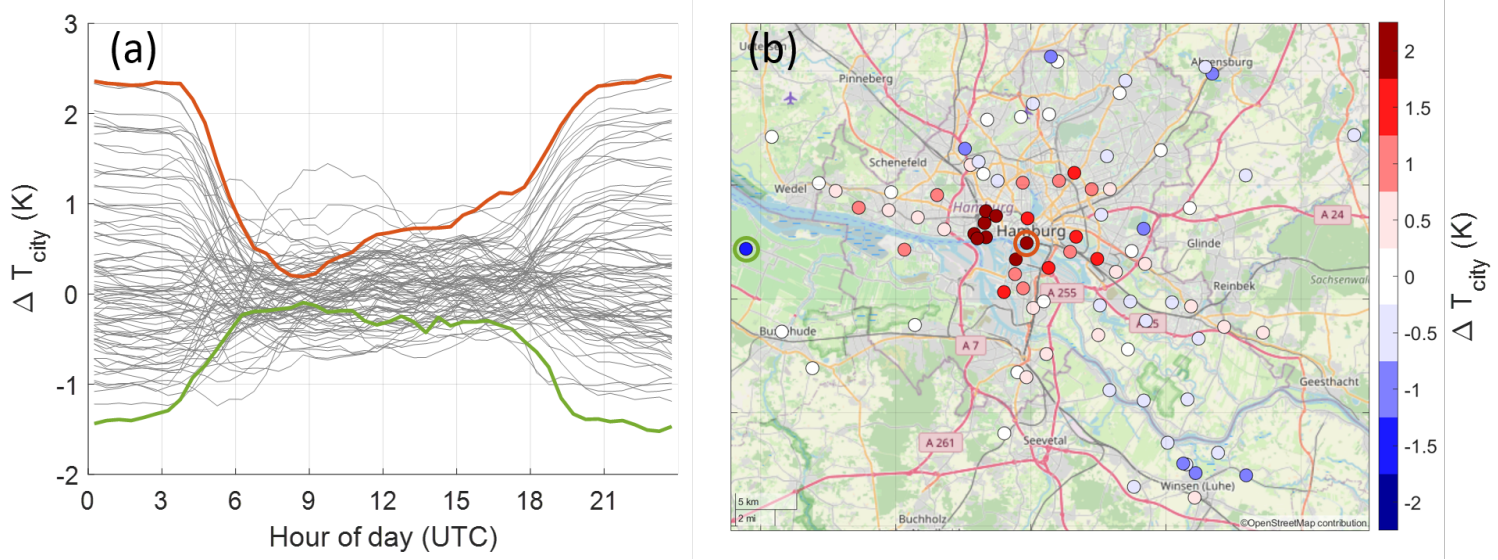

Figure 10. (a) Mean diurnal cycle of urban temperature modification $\Delta T_{\text {city }}$ and (b) nighttime (21:00 UTC to 03:00 UTC) mean of $\Delta T_{\text {city }}$ at all APOLLO and WXT stations from 15 June to 31 August 2020. Highlighted in orange and green are the stations Wetterstation HafenCity (010WSa) and Obsthof Schuback (055OGw), respectively. (C) OpenStreetMap contributors 2021. Distributed under the Open Data Commons Open Database License (ODbL) v1.0. 
https://doi.org/10.5194/essd-2021-424

Preprint. Discussion started: 3 March 2022

(c) Author(s) 2022. CC BY 4.0 License.

(c) (i)


Figure 11. (a) Mean diurnal cycle of standard deviation of $1 \mathrm{~min}$ temperature fluctuations $\sigma_{\mathrm{T}}$ at all APOLLO stations (grey lines) and at the highlighted stations Stadtteilschule Blankenese (yellow; 033KBa), Schule Redder (orange; 036KBa), Luftmessnetz, Rothenburgsort (blue; 020LMa) and Uni Sternwarte (green; 043UHa). Map data @ Google Earth 2021. (b) Net radiation at the Hamburg weather mast site dependent on $\sigma_{\mathrm{T}}$ at station Wetterstation Zollamt, both averaged over $10 \mathrm{~min}$. Blue boxes and orange bars indicate the inter-quartile range and median for the respective $\sigma_{\mathrm{T}}$ bin. The analyses in both (a) and (b) are valid for sunny days from 1 June to 31 August 2020, whereas sunny days are defined as days on which the daily averaged global radiation at Hamburg weather mast is larger than at least one-third of the daily averaged theoretical maximum of clear sky insolation. 
https://doi.org/10.5194/essd-2021-424

Preprint. Discussion started: 3 March 2022

(c) Author(s) 2022. CC BY 4.0 License.

Table 1. Sensor specifications of APOLLO station (TE Connectivity, 2015; Bosch, 2020).

\begin{tabular}{lcrr}
\hline Parameter & Sensor & Measurement range & Accuracy \\
\hline Temperature & NTC thermistor & $-40 \ldots 100^{\circ} \mathrm{C}$ & $\pm 0.2 \mathrm{~K}$ at $0 \ldots 70^{\circ} \mathrm{C}$ \\
Pressure & BME280 digital sensor & $300 \ldots 1100 \mathrm{hPa}$ & $\pm 1 \mathrm{hPa}$ at $0 \ldots 30^{\circ} \mathrm{C}$ (absolute) \\
& & $\pm 0.12 \mathrm{hPa}$ at $25 \ldots 40^{\circ} \mathrm{C}$ (relative) \\
\hline
\end{tabular}


https://doi.org/10.5194/essd-2021-424

Preprint. Discussion started: 3 March 2022

(c) Author(s) 2022. CC BY 4.0 License.

Table 2. Sensor specifications of WXT weather station (Vaisala, 2020).

\begin{tabular}{lccr}
\hline Parameter & Sensor & Measurement range & Accuracy \\
\hline Temperature & PTU module & $-52 \ldots 60{ }^{\circ} \mathrm{C}$ & $\pm 0.3 \mathrm{~K}$ at $20^{\circ} \mathrm{C}$ \\
& Pt1000 thermometer & $-50 \ldots 85^{\circ} \mathrm{C}$ & $\pm 1.3 \mathrm{~K}$ at $20^{\circ} \mathrm{C}$ \\
Pressure & PTU module & $500 \ldots 1100 \mathrm{hPa}$ & $\pm 0.5 \mathrm{hPa}$ at $0 \ldots 30^{\circ} \mathrm{C}$ \\
& & & $\pm 1.0 \mathrm{hPa}$ at $-52 \ldots 60^{\circ} \mathrm{C}$ \\
Relative humidity & PTU module & $0 \ldots 100 \% \mathrm{RH}$ & $\pm 3 \% \mathrm{RH}$ at $0 \ldots 90 \% \mathrm{RH}$ \\
& & & $\pm 5 \% \mathrm{RH}$ at $90 \ldots 100 \% \mathrm{RH}$ \\
Wind speed & Ultrasonic anemometer & $0 \ldots 60 \mathrm{~m} \mathrm{~s}^{-1}$ & $\pm 3 \%$ at $10 \mathrm{~m} \mathrm{~s}^{-1}$ \\
Wind direction & Ultrasonic anemometer & $0 \ldots 360^{\circ}$ & $\pm 3{ }^{\circ}$ at $10 \mathrm{~m} \mathrm{~s}^{-1}$ \\
Rainfall & Piezoelectrical sensor & - & better than $5 \%$, weather dependent \\
\hline
\end{tabular}


https://doi.org/10.5194/essd-2021-424

Preprint. Discussion started: 3 March 2022

(c) Author(s) 2022. CC BY 4.0 License.

Table 3. Meta data of APOLLO measurement sites. Altitude denotes the height of ground above sea level and sensor height is the height of temperature sensor above ground. See section 3.1 for explanation of local climate zones (LCZ) after Stewart and Oke (2012).

\begin{tabular}{|c|c|c|c|c|c|c|}
\hline Identifier & Name & Latitude $\left({ }^{\circ} \mathrm{N}\right)$ & Longitude $\left({ }^{\circ} \mathrm{E}\right)$ & Altitude (m) & Sensor height $(\mathrm{m})$ & LCZ \\
\hline 007WSa & Wetterstation Stellingen Wohngebiet & 53.59817 & 9.92575 & 21 & 3 & 6 \\
\hline 008WSa & Wetterstation Wilhelmsburg Grünfläche & 53.49349 & 10.00290 & 3 & 3 & 6 \\
\hline 010WSa & Wetterstation HafenCity & 53.54109 & 9.99505 & 8 & 2 & 5 \\
\hline 011WSa & Wetterstation Zollamt & 53.52393 & 10.09486 & 6 & 3 & 8 \\
\hline 015LMa & Luftmessnetz Max-Brauer-Allee & 53.55571 & 9.94306 & 25 & 3 & 2 \\
\hline 016LMa & Luftmessnetz Kieler Straße & 53.56440 & 9.94464 & 17 & 3 & 2 \\
\hline 018LMa & Luftmessnetz Habichtstraße & 53.59240 & 10.05374 & 13 & 3 & 5 \\
\hline 019LMa & Luftmessnetz Elbhang & 53.54523 & 9.94488 & 23 & 3 & 5 \\
\hline 020LMa & Luftmessnetz Rothenburgsort & 53.53463 & 10.04861 & 4 & 3 & 5 \\
\hline 021LMa & Luftmessnetz Stresemannstraße & 53.56086 & 9.95733 & 21 & 3 & 2 \\
\hline 022LMa & Luftmessnetz Neugraben & 53.48101 & 9.85715 & 3 & 3 & 6 \\
\hline 023LMa & Luftmessnetz Wilhelmsburg & 53.50789 & 9.99059 & 3 & 3 & 6 \\
\hline 024LMa & Luftmessnetz Hafen & 53.52910 & 9.98163 & 6 & 3 & 8 \\
\hline 025LMa & Luftmessnetz Veddel & 53.52287 & 10.02204 & 5 & 3 & $5 \mathrm{G}$ \\
\hline 026LMa & Luftmessnetz Billbrook & 53.52945 & 10.08207 & 5 & 3 & $8 \mathrm{G}$ \\
\hline 027KBa & Saselbekstraße, Sasel & 53.65976 & 10.11679 & 30 & 3 & 6 \\
\hline $028 \mathrm{KBa}$ & Halepaghen Schule, Buxtehude & 53.47613 & 9.69293 & 3 & 2 & 6 \\
\hline 029KBa & Stadtteilschule Eidelstedt & 53.60816 & 9.89548 & 19 & 3 & 6 \\
\hline 030KBa & Stadtteilschule Meiendorf & 53.62835 & 10.16431 & 40 & 2 & 6 \\
\hline $031 \mathrm{KBa}$ & Gymnasium Rahlstedt & 53.60212 & 10.14735 & 31 & 2 & 6 \\
\hline 033KBa & Stadtteilschule Blankenese & 53.56509 & 9.82479 & 39 & 3 & 6 \\
\hline 036KBa & Schule Redder, Sasel & 53.65064 & 10.10965 & 38 & 2 & 6 \\
\hline 037UHa & Uni Physik DESY, Bahrenfeld & 53.57615 & 9.88457 & 38 & 3 & 5 \\
\hline 039UHa & Uni Campus, Rotherbaum & 53.56615 & 9.98540 & 12 & 3 & 5 \\
\hline 040UHa & Geomatikum, Balkon 16. Stock & 53.56831 & 9.97495 & 16 & 68 & 4 \\
\hline 041UHa & Uni Botanischer Garten, Klein Flottbek & 53.55979 & 9.86068 & 29 & 3 & 5 \\
\hline 043UHa & Uni Sternwarte, Bergedorf & 53.47964 & 10.23859 & 31 & 3 & $6 \mathrm{~A}$ \\
\hline $046 \mathrm{OGa}$ & BAW Rissen & 53.58492 & 9.73867 & 11 & 3 & $6 \mathrm{~A}$ \\
\hline 049OGa & Horner Rennbahn & 53.56176 & 10.08700 & 14 & 3 & 6 \\
\hline 051OGa & Drachenwiese Winsen & 53.37231 & 10.20341 & 4 & 3 & $\mathrm{~B}$ \\
\hline $052 \mathrm{OGa}$ & HAW Campus Bergedorf & 53.49469 & 10.19780 & 19 & 3 & 5 \\
\hline 053OGa & Hamburger Bogengilde, Fuhlsbüttel & 53.64289 & 10.00270 & 21 & 3 & $6 \mathrm{D}$ \\
\hline $054 \mathrm{OGa}$ & Obsthof Lehmbeck, Hoopte & 53.39460 & 10.16881 & 3 & 3 & 9 \\
\hline
\end{tabular}


https://doi.org/10.5194/essd-2021-424

Preprint. Discussion started: 3 March 2022

(c) Author(s) 2022. CC BY 4.0 License.

Table 3. (continued)

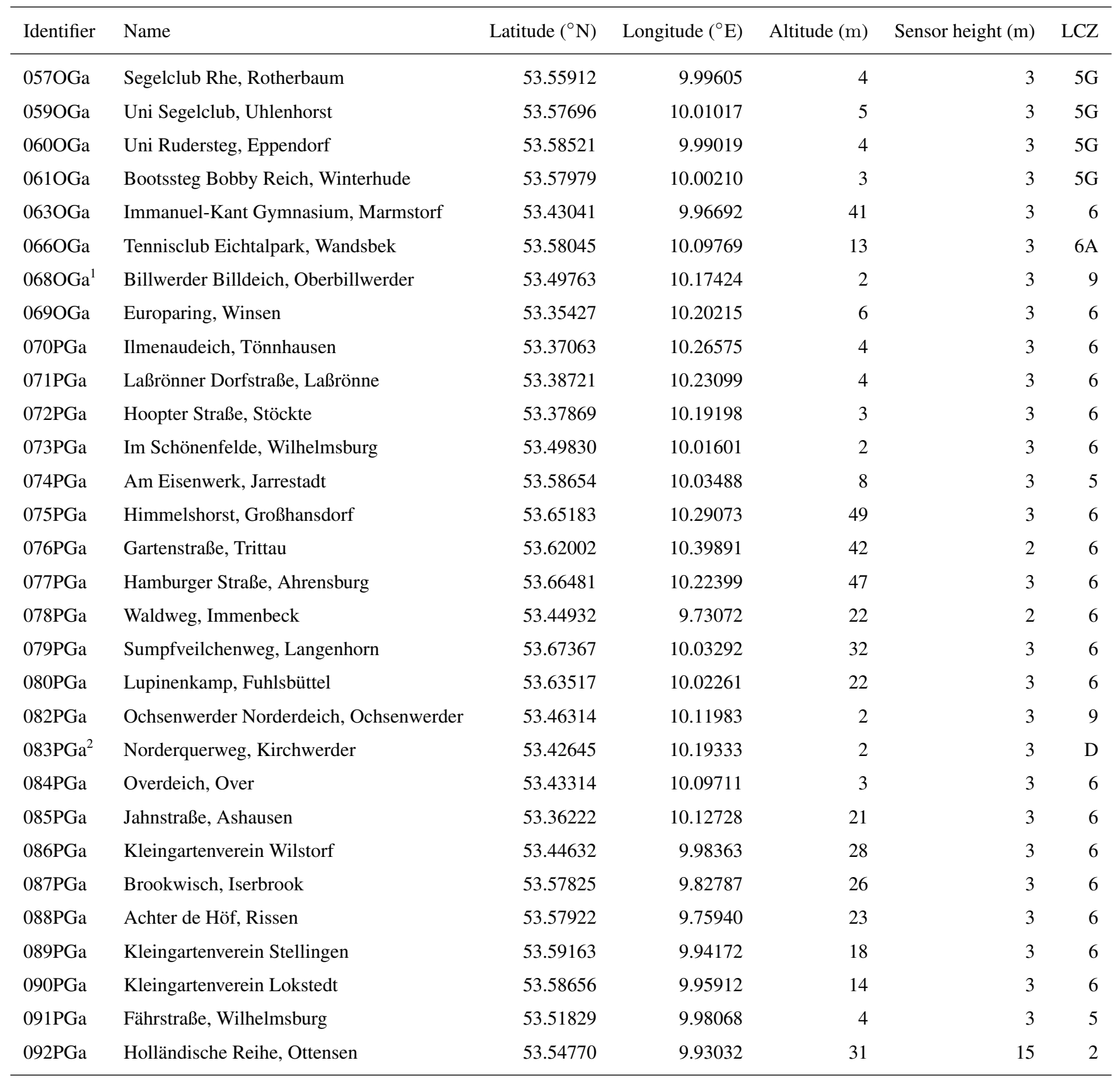

${ }^{1}$ APOLLO station replaced on 25 June 2020

${ }^{2}$ APOLLO station replaced by WXT station on 25 June 2020 
https://doi.org/10.5194/essd-2021-424

Preprint. Discussion started: 3 March 2022

(c) Author(s) 2022. CC BY 4.0 License.

Table 3. (continued)

\begin{tabular}{|c|c|c|c|c|c|c|}
\hline Identifier & Name & Latitude $\left({ }^{\circ} \mathrm{N}\right)$ & Longitude $\left({ }^{\circ} \mathrm{E}\right)$ & Altitude $(\mathrm{m})$ & Sensor height $(\mathrm{m})$ & $\mathrm{LCZ}$ \\
\hline 093PGa & Kleingartenverein Niendorfer Gehege & 53.61008 & 9.91888 & 12 & 3 & 6 \\
\hline 094PGa & Harzburger Weg, Niendorf & 53.63124 & 9.94628 & 21 & 3 & 6 \\
\hline 095PGa & Rantzaustraße, Ahrensburg & 53.66977 & 10.21542 & 47 & 3 & 6 \\
\hline 096PGa & Godenwind, Mümmelmannsberg & 53.52577 & 10.14109 & 30 & 3 & 6 \\
\hline 097PGa & Parchimer Straße, Rahlstedt & 53.60891 & 10.16041 & 30 & 3 & 6 \\
\hline 098PGa & Musilweg, Wilstorf & 53.44273 & 9.99474 & 27 & 3 & 6 \\
\hline 099PGa & Schlossgarten, Wandsbek & 53.57030 & 10.06929 & 13 & 3 & 6 \\
\hline $100 \mathrm{PGa}$ & Hamfelderedder, Börnsen & 53.47537 & 10.28655 & 55 & 3 & 6 \\
\hline $102 \mathrm{PGa}$ & Abelke-Bleken-Ring, Ochsenwerder & 53.47363 & 10.08330 & 1 & 3 & 6 \\
\hline $103 \mathrm{PGa}$ & Burbekstraße, Eidelstedt & 53.61903 & 9.87959 & 22 & 3 & 6 \\
\hline $104 \mathrm{PGa}$ & Luxweg, Billwerder & 53.49826 & 10.12280 & 1 & 3 & 6 \\
\hline $105 \mathrm{PGa}$ & Barsbütteler Landstraße, Barsbüttel & 53.56667 & 10.19619 & 37 & 3 & 6 \\
\hline $106 \mathrm{PGa}$ & Kleingartenverein Allermöhe & 53.48406 & 10.14210 & 2 & 3 & 6 \\
\hline 107PGa & Ansorgestraße, Othmarschen & 53.55108 & 9.89326 & 23 & 3 & 6 \\
\hline $108 \mathrm{PGa}$ & Auf dem Königslande, Wandsbek & 53.58045 & 10.07517 & 15 & 3 & 5 \\
\hline 109PGa & Eenstock, Bramfeld & 53.60457 & 10.09405 & 18 & 3 & 6 \\
\hline $111 \mathrm{OGa}$ & Suntrace, Altona & 53.54436 & 9.93413 & 5 & 10 & $5 \mathrm{G}$ \\
\hline $112 \mathrm{PGa}$ & Teubnerweg, Billstedt & 53.53520 & 10.12454 & 17 & 3 & 6 \\
\hline $113 \mathrm{PGa}$ & Steinbeker Straße, Hamm & 53.54563 & 10.05597 & 6 & 7 & $5 \mathrm{G}$ \\
\hline
\end{tabular}


https://doi.org/10.5194/essd-2021-424

Preprint. Discussion started: 3 March 2022

(c) Author(s) 2022. CC BY 4.0 License.

Table 4. As Table 3, but for WXT measurement sites.

\begin{tabular}{|c|c|c|c|c|c|c|}
\hline Identifier & Name & Latitude $\left({ }^{\circ} \mathrm{N}\right)$ & Longitude $\left({ }^{\circ} \mathrm{E}\right)$ & Altitude (m) & Sensor height (m) & $\mathrm{LCZ}$ \\
\hline 002MIw & Wettermast, Billwerder & 53.51996 & 10.10515 & 1 & 3 & $6 \mathrm{D}$ \\
\hline 004MIw & Wasserwerk Baursberg, Blankenese & 53.56692 & 9.78784 & 82 & 2 & 6 \\
\hline 005WSw & Wetterstation Langenhorn Grünfläche & 53.67731 & 10.02480 & 24 & 3 & $6 \mathrm{~B}$ \\
\hline 006WSw & Wetterstation Stellingen Grünfläche & 53.60056 & 9.93568 & 14 & 3 & $6 \mathrm{~B}$ \\
\hline 017LMw & Luftmessnetz Finkenwerder & 53.53621 & 9.84419 & 6 & 5 & 6 \\
\hline $035 \mathrm{KBw}$ & Gut Karlshöhe, Bramfeld & 53.63052 & 10.11114 & 31 & 3 & 6 \\
\hline 044OGw & Fährhaus Tatenberg & 53.49537 & 10.08528 & 2 & 3 & 9 \\
\hline 045OGw & Windpark Curslack & 53.47102 & 10.20700 & 2 & 3 & $\mathrm{D}$ \\
\hline 047OGw & Bogenwiese Holm & 53.61872 & 9.68062 & 15 & 3 & 6 \\
\hline $048 \mathrm{OGw}^{1}$ & Segelflugplatz Boberg & 53.51360 & 10.15142 & 2 & 3 & 9 \\
\hline 050OGw & Bogenschießplatz Stöckte & 53.37930 & 10.18809 & 1 & 3 & $6 \mathrm{D}$ \\
\hline $055 \mathrm{OGw}$ & Obsthof Schuback, Mittelnkirchen & 53.53679 & 9.64878 & 1 & 3 & B \\
\hline 062OGw & Segelverein Neuländer See & 53.45972 & 10.01936 & 1 & 3 & $9 \mathrm{G}$ \\
\hline 0640Gw & Biohof Obermeyer, Emmelndorf & 53.40151 & 9.96742 & 49 & 3 & 9 \\
\hline $065 \mathrm{OGw}$ & Greenpeace, Wilhelmsburg & 53.50515 & 9.96698 & 8 & 3 & $10 \mathrm{G}$ \\
\hline 067OGw & DWD Flughafen, Fuhlsbüttel & 53.63327 & 9.98796 & 9 & 3 & 9 \\
\hline 081PGw & Süderquerweg, Kirchwerder & 53.42561 & 10.13946 & 3 & 3 & 6 \\
\hline 083PGw & Norderquerweg, Kirchwerder & 53.42645 & 10.19333 & 2 & 3 & $\mathrm{D}$ \\
\hline $101 \mathrm{PGw}$ & Reinbeker Weg, Brunsbek & 53.59054 & 10.26513 & 58 & 3 & 6 \\
\hline $110 \mathrm{OGw}$ & Öjendorfer See, Billstedt & 53.55152 & 10.13930 & 13 & 3 & B \\
\hline $114 \mathrm{UHw}^{2}$ & Geomatikum, Dachterasse 18. Stock & 53.56819 & 9.97483 & 16 & 72 & 4 \\
\hline
\end{tabular}

${ }^{1}$ WXT536 sensor replaced on 31 July 2020

${ }^{2}$ WXT536 sensor replaced on 10 June 2020 